\title{
Investigating The Environmental Kuznets Curve (Ekc) Hypothesis For India: Does India Have Enough Capital To Supplement Renewable Energy Usage In The Correction of Carbon Emissions?
}

Soumen Rej ( $\nabla$ soumen.rej@iitkgp.ac.in )

Indian Institute of Technology Kharagpur https://orcid.org/0000-0001-9098-9286

Barnali Nag

Indian Institute of Technology Kharagpur

\section{Research Article}

Keywords: Renewable energy (RE) consumption, economic growth, CO2 emissions, EKC, ARDL, energy policy, India.

Posted Date: December 6th, 2021

DOI: https://doi.org/10.21203/rs.3.rs-1061246/v1

License: (c) (i) This work is licensed under a Creative Commons Attribution 4.0 International License.

Read Full License 


\title{
Investigating The Environmental Kuznets Curve (Ekc) Hypothesis For India: Does India Have Enough Capital To Supplement Renewable Energy Usage In The Correction Of Carbon Emissions?
}

\author{
Soumen $\mathbf{R E} \mathbf{J}^{1}$ \\ ${ }^{1}$ Vinod Gupta School of Management, Indian Institute of Technology Kharagpur, West \\ Bengal, India, Email: soumen.rej@iitkgp.ac.in \\ Barnali Nag ${ }^{1}$ \\ ${ }^{1}$ Vinod Gupta School of Management, Indian Institute of Technology Kharagpur, West \\ Bengal, India, Email: barnali.nag@ vgsom.iitkgp.ac.in \\ *Correspondence: Soumen Rej (Email: soumen.rej@iitkgp.ac.in)
}

\section{Abstract}

India's sustainable development goals consist of higher economic growth through strengthening of the manufacturing sector on the one hand and ambitious carbon emission reduction plans through increased renewables on the other. This paper studies the dynamic association between $\mathrm{CO}_{2}$ emissions, economic growth, renewable energy (RE) consumption and gross capital formation and tests for the existence of Environmental Kuznets Curve (EKC) hypothesis for India over the time period 1970-2018. It also tries to see if there is any possible conflict between the economic and energy goals using an interaction term between RE consumption and gross capital formation. The empirical results not only confirm long run relationship among the underlying variables but also indicate an ' $\mathrm{N}$ ' shaped EKC in the long run for India indicating a departure from the traditional inverted U-shaped EKC hypothesis. $\mathrm{RE}$ consumption is found to reduce emissions, whereas gross capital formation and the interaction term between RE consumption and gross capital formation are found to raise emissions in the long run. The study concludes that India needs to align its economic policy of 'Make in India' with its energy policy so that investments under the former facilitate extensive penetration, adaptation and usage of renewable energy. A policy dichotomy between the two goals may defeat India's INDC objective of drastic reduction in $\mathrm{CO}_{2}$ emissions through increased renewables by 2030 . 
31 Keywords: Renewable energy (RE) consumption, economic growth, $\mathrm{CO}_{2}$ emissions, EKC,

32 ARDL, energy policy, India.

33

\section{Introduction}

India being one of the fastest-developing economies of the world, increasing trend of $\mathrm{CO}_{2}$ emissions is a challenge while designing sustainable energy policy framework for India which can strike a balance between economic competitiveness, energy security and environmental protection. The anthropogenic $\mathrm{CO}_{2}$ emissions from fuel combustion of India was estimated $2162 \mathrm{Mt}$ in the year 2017, mainly attributed to the rapid expansion of energy sector and industrial sector contributing $50.9 \%$ and $26.1 \%$ of total of total $\mathrm{CO}_{2}$ emissions respectively (IEA, 2020). Extensive research has been done till date to identify the pattern of relationship between economic growth and environmental degradation well known as Environmental Kuznets curve hypothesis based on the inverted $U$ shape relationship between economic development and income inequality established by Nobel winner economist Simon Kuznets.

The Government of India has undertaken various policy measures to control its greenhouse gas emissions by 2030 as an integral part of its Intended Nationally Determined Contributions (INDC) commitment at the conclusion of UNFCCC Paris agreement 2015 through reduction of greenhouse emissions intensity of GDP by $33-35 \%$ by 2030 from 2005 by enhancing share of renewables by $40 \%$ in installed capacity with the help of technology transfer and forming green climate fund and aiming for additional carbon sink of 2.5-3 billion tonnes of $\mathrm{CO}_{2}$ equivalent with the aid of forestation and plantation of tree (MoEFCC, 2015). Consequently, India's energy sector is also undergoing a transient shift towards low carbon energy pathway through enhanced capacity addition of renewables in national energy portfolio not only as a precautionary measure of air quality deterioration but also to meet the energy aspirations of 1.4 billion citizens of India. India's per capita renewable energy consumption has increased by 2.5 
times over the year 1970 to 2018 . As of 2019 , India had around $118 \mathrm{GW}$ renewable energy (RE) generation capacity with aim to expand to 175 GW by 2022 (Energy Statistics, 2020). India is the first country in the world to establish an entire ministry for promotion of renewable energy and held second position in 2017 "Renewable Energy Attractiveness Index" released by Ernst \& Young. At the same time, Government of India took alternate action plans to electrify all the census villages by 2018 and to provide 24 x 7 access to electricity by 2022 (NITI Aayog, 2017) to ensure 100\% energy security as a supplement of SDG-7. Despite the Government's ambitious target, only $86 \%$ rural electrification was witnessed in 2018, while the Ministry of Power proclaimed a power surplus of 174GW peak energy demand in the same timeline (Ministry of Power, 2018). One of the reasons behind the scarcity in power supply to the remaining $14 \%$ of the rural households lies in the lack of capital investment required by DISCOMS to procure sufficient amount of power to serve the deprived rural households. So, capital formation can be viewed as one of the major impediments in the objective of $100 \%$ electrification for India and hence accelerating the economic engine of the country. Penetration of renewable energy in the economy needs enormous capital along the entire innovation chain of renewable energy use, starting from research and development in technology development to setting up of full scale power plants (Mazzucato and Semienluk, 2018). Most of the energy related capital stock and investments of the Indian economy currently is aligned toward fossil fuel use which is the primary source of energy for functioning of the economy. Any attempt to make a shift toward renewables to substitute fossil fuel consumption would require not only investment in generation but also in entire restructuring of energy usage in the economy through investment in developing transmission and distribution system and energy storage on the supply side and clean energy applications and usage on the demand side (WEF, 2019). Ministry of New and Renewable Energy (MNRE) has invested around USD 62.52 million over 2012-2017 and aiming to double the budget in the current three-year plan period. India has also 
received around USD 6.84 billion FDI inflows in renewable sector over the period 2000-2018 and expecting to attract around USD 80 billion over the period 2018-22 through foreign and domestic investors (Majid, 2020). However, all of this investment is primarily aimed at increasing generation capacity and it is uncertain if investment of this magnitude would be sufficient to push usage of renewables to substitute fossil fuels in the future. IEEFA (2019) reports that India's target of $523 \mathrm{GW}$ of renewable energy in 2030 calls for investments to the tune of $\$ 500$ to $\$ 700$ billion in renewable energy sector and grid network over the next decade.

The purpose of this study is to examine the existence of an Environmental Kuznets Curve for India and scrutinizing the long run dynamics between economic growth, $\mathrm{CO}_{2}$ emissions, $\mathrm{RE}$ consumption, gross capital formation and the interaction effect between RE consumption and gross capital formation. Increasing economic activity and rise in share of manufacturing is likely to be associated with increased capital formation, the impact of which on emission is uncertain. Also, adoption of RE into the economy needs adequate capital infusion to support the adoption of a RE consumption path. Hence, we have included an interaction term to test the composite impact of capital increase in the economy along with increased renewable energy usage.

The structure of the paper is organized as follows: Section 2 provides literature reviews encompassing EKC with special reference to India, Section 3 provides theoretical underpinning and econometric specifications, Section 4 describes data, Section 5 outlines the methodology, Section 6 discusses the results, and Section 7 follows with conclusion and policy implications.

\section{Literature Review}

The empirical investigations of growth-energy-emission nexus has been receiving wide attention over the last few decades among the environmental economists and policy scientists 
environmental economics. The existing vast body of literature exploring the relationship between energy consumption, economic growth and environmental degradation can broadly be categorized into three key strands of research.

The first stream of research examines the relationship between economic growth and energy consumption. The causal linkage between economic growth and energy consumption can be classified into four key hypotheses. The first hypothesis is identified as growth hypothesis that studies the existence of long run unidirectional causality from energy consumption to economic growth (Asafu-Adjaye, 2000; Soytas and Sari, 2003; Apergis and Payne, 2009a; Iyke, 2015; Shastri et al., 2020). The second is the conservation hypothesis that shows unidirectional causality from economic growth to energy consumption (Al-Iriani, 2005; Akinlo, 2008; Tugcu et al., 2012; Bildirci, 2013; Furuoka, 2017). The third hypothesis is well known as feedback hypothesis that confirms the bidirectional causal relationship between energy consumption and economic growth (Moubarak, 2014; Apergis and Payne, 2009b; Fuinhas and Marques, 2012; Belke at al., 2011; Nazlioglu et al., 2014). Finally, the neutrality hypothesis confirms absence of any causal linkage between energy consumption and economic growth (Asghar, 2008; Cheng, 1997; Tugcu et al., 2012).

The second strand of research focuses on the dynamic relationship between economic growth and environmental degradation which is popular as 'Environmental Kuznets Curve' (EKC) hypothesis. There is plethora of literature examining the EKC hypothesis in region specific/ country specific/ multiple country studies utilizing different indicators of air quality assessments like $\mathrm{CO}_{2}, \mathrm{SO}_{2}, \mathrm{NO}_{x}, \mathrm{PM}_{2.5}$, etc. The relationship between environment degradation and economic growth was initially captured as a inverted U shaped curve implying that in an economy, emissions would rise with economic growth and reach a peak, after which it would start declining with further growth in national income. Some of the studies which show inverted U shape EKC include Halicioglu (2009), He and Richard (2010), Ahmed and Long 
(2012), Destek and Sarkodie (2019), Nasir and Rehman (2011), Saboori et al. (2012), Wang et al. (2016), Ding et al. (2019), Apergies and Ozturk (2015), Jebli et al. (2016), Ahmed et al. (2016), Pata (2018), Işı et al. (2019), Bekun et al. (2019). Later, some studies have also estimated the existence of an N shaped EKC, like Akbostanc1 et al. (2009), Menéndez et al. (2014), Özokcu and Özdemir (2017), Pal and Mitra (2017), Allard et al. (2018), Churchill at al. (2018). Dinda (2004), Al-Mulali et al. (2015), and Sarkodie and Strezov (2019).

Finally, the third stream of research has taken the opportunity to merge the first two approaches exploring the dynamic relationship between economic growth, energy consumption (both aggregate and disaggregate level) and environmental degradation. These studies include Ang (2007), Soytas et al. (2007), Ghosh (2010), Sebri and Ben- Salha (2014), Jebli and Youssef (2017), Appiah (2018), Gorus and Aydin (2019).

There are some studies providing insights to the existence of EKC hypothesis for India. However, the findings related to existence of EKC hypothesis for India remains inconclusive and the shape of the curve is found to be mixture of both inverted ' $U$ ' shape and ' $N$ ' shape. Jayanthakumaran et al. (2012) examined the EKC hypothesis for both India and China for the period 1971-2007 by employing ARDL methodology and provided the evidence of inverted ' $U$ ' shape EKC hypothesis for both of the countries although the result of $F$ test of ARDL bounds test of co-integration was found to be inconclusive for both the countries. The findings of this study suggest that while $1 \%$ increase of per capita GDP is associated with $1.62 \%$ increase of per capita $\mathrm{CO}_{2}$ emissions for China, the effect is found to be more detrimental to India resulting in 3.8 times more per capita $\mathrm{CO}_{2}$ emissions for India compared to China. Tiwari et al. (2013) confirmed the existence of inverted 'U' shape EKC hypothesis for India in both short run and long run while examining the dynamic relationship between coal consumption, $\mathrm{CO}_{2}$ emissions, economic growth and trade openness for the period of 1966-2009 by employing ARDL methodology. The empirical findings of this study strongly suggest the evidence of 
feedback hypothesis between $\mathrm{CO}_{2}$ emissions and economic growth in short run and long run elasticity of per capita coal consumption and per capita trade openness was estimated 0.844 and 0.086 respectively. Kanjilal and Ghosh (2013) established regime shift co-integration between $\mathrm{CO}_{2}$ emissions, economic growth, energy use and trade openness for the annual data of 1971-2008 by utilizing regime shift co-integration methodology. This study supported the existence of inverted ' $\mathrm{U}$ ' shape EKC hypothesis for India and concluded that per capita $\mathrm{CO}_{2}$ emission is highly elastic with respect to both per capita income and energy consumption. Sinha and Shahbaz (2018) found inverted ' $U$ ' shape EKC for India while examining long run relationship between $\mathrm{CO}_{2}$ emissions, economic growth, renewable energy generation, electric power consumption and international trade for the data period of 1971-2015. While various studies provided evidence of inverted ' $U$ ' shape relationship between economic growth and carbon dioxide emissions for India, Pal and Mitra (2017) provided empirical evidence of existence of $\mathrm{N}$ shape EKC for India for the data period 1971-2012 while performing a comparative analysis between India and China in the context of EKC framework. This study primary energy supply, trade openness and financial development for India for 1971-2016 although the empirical evidence does not support the holding of EKC hypothesis for India.

\section{Theoretical framework and econometric specification}

The dynamic association between environmental pollution and economic growth is wellknown as environmental Kuznets curve hypothesis ${ }^{1}$. According to this hypothesis, pollution increases rapidly with increase in per capita income as at this stage policy makers are more

\footnotetext{
${ }^{11}$ The hypothesis derives its name from a similar hypothesis between income and inequality proposed by Kuznets (1955)
} 
concerned with job creation and income over paying heed to the environmental consequences.

177 As economy expands with higher level of per capita income and more usage of environment friendly energy efficient technology, pollution level starts decreasing as people become more conscious about environment and start demanding cleaner environment and energy consumption pattern shifts toward modern cleaner energy sources. High income is also able to afford more efficient and cleaner technology. This relationship between economic growth and pollution follows an inverted U shaped curve called Environmental Kuznets Curve (Dasgupta et al., 2002; Dinda, 2004; Nasir and Rehman, 2011; Saboori et al., 2012). There are some evidences of $\mathrm{N}$ shaped environmental Kuznets curve that depicts that pollution level increases rapidly in the initial phase with the increase of per capita income, after reaching a peak, pollution level then starts falling with increase of per capita income. With further expansion of economic activity, pollution level is again found to exhibit steady increase. (Pal and Mitra, 2017; Churchill at al., 2018; Allard et al., 2018).

In this study, we apply the EKC framework to test the relationship between $\mathrm{CO} 2$ emissions and per capita income in the long run and investigating the existence of environmental Kuznets curve hypothesis for India. Also, it is proposed that there is a dynamic linkage between renewable energy consumption and $\mathrm{CO}_{2}$ emissions as renewable energy alternatives are becoming important in energy portfolio of most countries and emerging as one of the major contributors towards reduction of $\mathrm{CO}_{2}$ emissions (Dong et al., 2017; Bilgili at al., 2016).

Additionally, gross capital formation has also been considered as a control variable in the EKC framework since capital formation may improve or worsen emissions in an economy. Capital formation through machinery and infrastructure for which energy usage is complementary will raise emissions (Rahman and Ahmad, 2019). Capital formation will be beneficial to the environment if capital creation is in environment friendly and energy conserving assets such as software, computer, service industry and energy efficient machineries that boost energy 
efficiency while reducing energy intensity (Bekun et al., 2019). The estimation of EKC with

202

203

204

205

206

207

208

209

210

211

212

213

214

215

216

217

218

219

220

221

222 the presence of renewable energy consumption and gross capital formation can be specified as follows:

$C_{t}=f\left(Y_{t}, Y_{t}^{2}, Y_{t}^{3}, R E C_{t}, G C F_{t}, R E C_{t} \times G C F_{t}\right)$

The above specification is converted into log-linear form as log-linear estimation can produce more efficient and consistent estimates as compared to linear model (Lau et al., 2014) and can be written as follows:

$\ln C_{t}=\alpha_{0}+\alpha_{1} \ln Y_{t}+\alpha_{2} \ln Y_{t}^{2}+\alpha_{3} \ln Y_{t}^{3}+\alpha_{4} \ln R E C_{t}+\alpha_{5} \ln G C F_{t}+\alpha_{6}\left(\ln R E C_{t} \times\right.$ $\left.\ln G C F_{t}\right)+\varepsilon_{t}$

Where $\mathrm{C}_{\mathrm{t}}$ represents $\mathrm{CO}_{2}$ emission per capita, $\mathrm{Y}_{\mathrm{t}}$ captures per capita real GDP, $\mathrm{Y}_{\mathrm{t}}{ }_{\mathrm{t}}$ denotes square of real GDP per capita, $\mathrm{Y}^{3}$ represents cube of real GDP per capita, $\mathrm{REC}_{\mathrm{t}}$ stands for renewable energy consumption per capita, $\mathrm{GCF}_{\mathrm{t}}$ captures gross capital formation per capita, $\left(\mathrm{REC}_{\mathrm{t}} \times \mathrm{GCF}_{\mathrm{t}}\right)$ indicates the interaction term between renewable energy consumption per capita and gross capital formation per capita to allow for indirect effect and $\varepsilon_{t}$ is the random error term.

If theoretically inverted U shaped Environmental Kuznets curve hypothesis holds true, then expected sign of $\alpha_{1}$ should be positive and statistically significant whereas expected sign of $\alpha_{2}$ should be negative and statistically significant. A positive and statistically significant value of $\alpha_{3}$ signals the existence of $\mathrm{N}$ shaped EKC. The expected value of $\alpha_{4}<0$. The sign of $\alpha_{5}$ can be either positive or negative. Sign of $\alpha_{6}$ is ambiguous depending on the strength of each of the effects of both renewable energy consumption per capita and gross capital formation per capita. If gross capital formation in the economy has been conducive to RE use, then the coefficient of the interaction term can be expected to be negative. On the other hand, if the capital addition 
to the economy has mostly been complementary to increased overall fuel use in the economy, the interaction term would have a positive coefficient.

\section{Data}

227

The present study uses forty-nine years of annual time series data spanning from1970-2018 for $\mathrm{CO}_{2}$ emissions, population, GDP, renewable energy consumption and gross capital formation. Population data is used to convert the variables into per capita form. The multivariate framework for the present study includes the $\mathrm{CO}_{2}$ emissions per capita measured in metric tons, real GDP per capita as a proxy of economic well being measured in constant 2010 US\$, per capita gross capital formation measured in constant LCU and per capita renewable energy consumption measured in tonnes of oil equivalent. Renewable energy consumption comprises of renewable electricity consumption from hydro, solar, wind, biomass, geothermal and other types of renewable energy sources. The data for real GDP, population and gross capital formation are taken from World Bank and data for all sources of renewable energy consumption are taken from BP Statistical Review of World Energy to compute the total renewable energy consumption. The data for $\mathrm{CO}_{2}$ emissions has been sourced from $\mathrm{BP}$ Statistical Review of World Energy. As the variables are in different dimensions, natural logarithmic transformation is essential for standardization purpose and to induce stationarity in the series of variables.

\section{Methodology}

The prime motivation behind this study is to empirically explore the relationship between $\mathrm{CO} 2$ emissions and economic growth for India explicitly in the presence of renewable energy consumption, gross capital formation and interaction effect between renewable energy consumption and gross capital formation in the environmental Kuznets curve framework following the existing empirical investigations for India (Tiwari et al., 2013; Pal and Mitra, 
248 2017; Rana and Sharma, 2018; Sinha and Shahbaz, 2018; Alam and Adil, 2019). The 249 comprehensive econometric methodology in our present study will embrace a four-stage 250 process. First, the order of integration of the variables will be tested using the traditional unit 251 root test approach (i.e., ADF and PP). Second, the long run relationship among the variables 252 will be investigated through ARDL bounds test co-integration technique and the long run coefficient estimates will be determined through the estimation of ARDL. Third, the robustness check of the ARDL bounds test co-integration technique will be validated through Bayer and Hanck's (2013) combined co-integration analysis and the robustness of the estimations of the ARDL model will be validated through the DOLS, FMOLS and CCR method. Finally, the

257 
Figure 1: Flowchart of the Econometric model analysis

Step 1: Test for Unit Roots
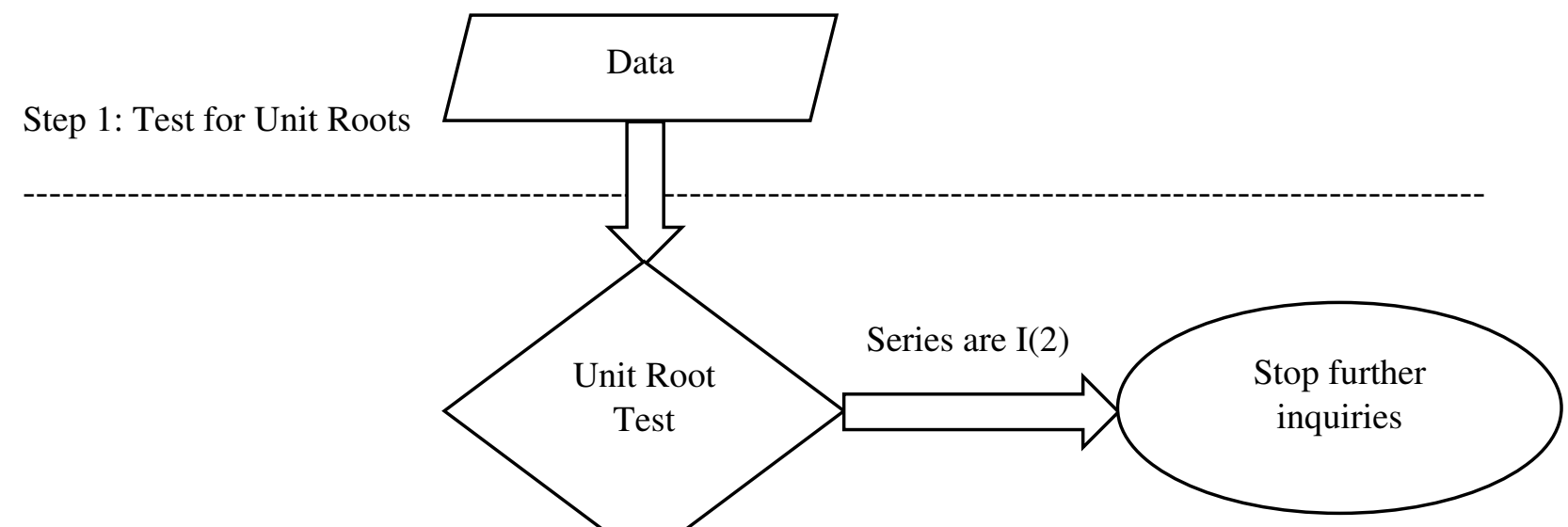

Step 2: Test for Co-integration
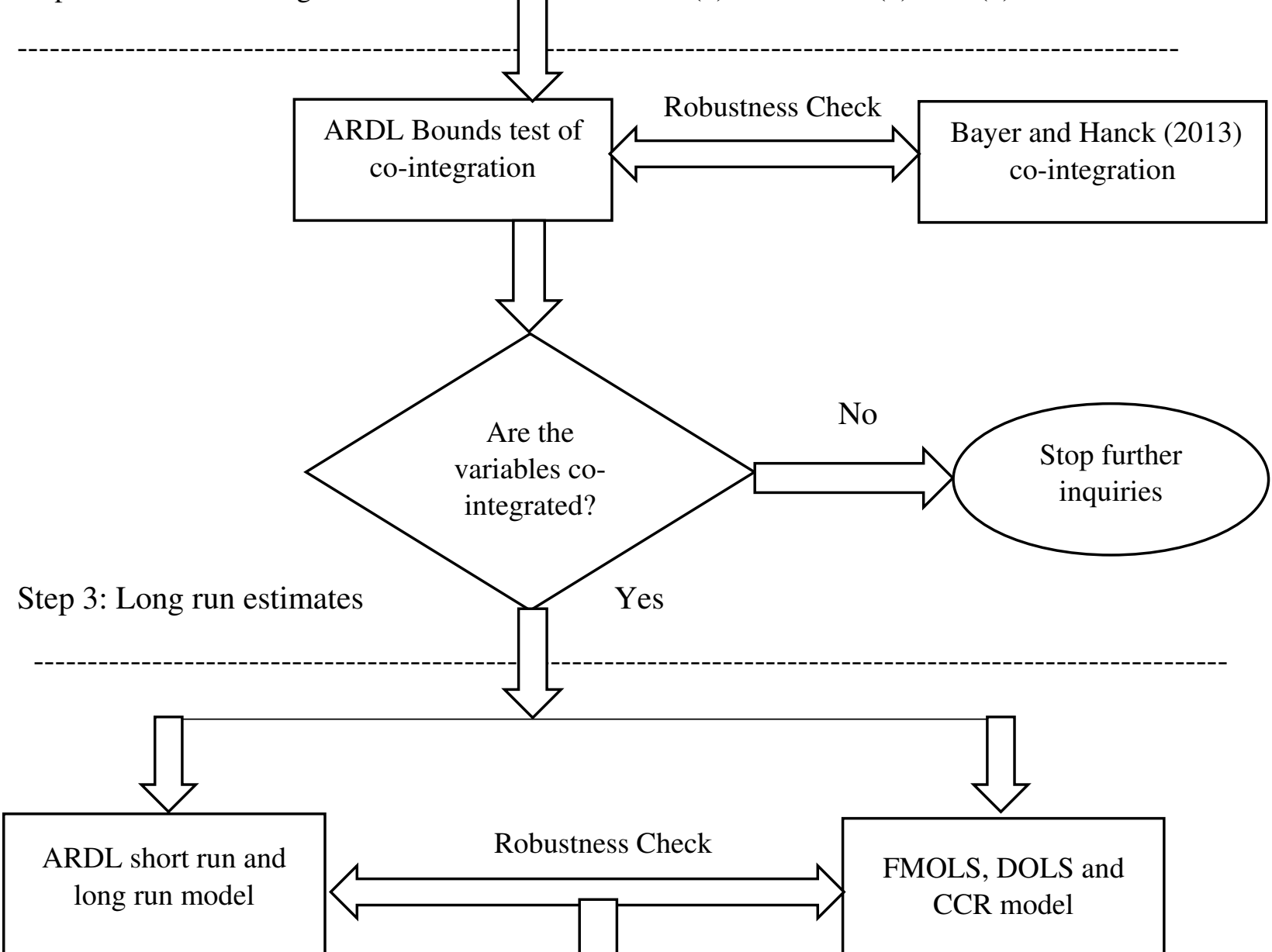

Series are $\mathrm{I}(1) /$ mixture of $\mathrm{I}(0)$ and $\mathrm{I}(1)$

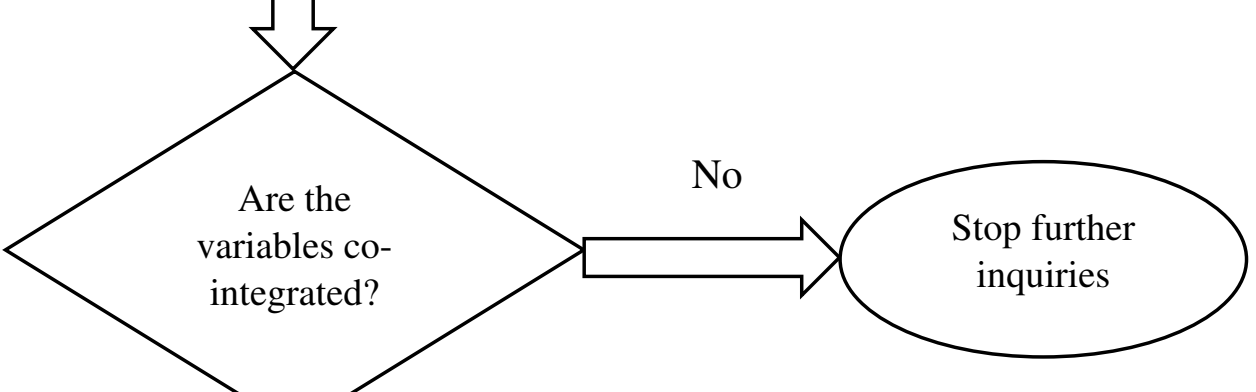

Step 3: Long run estimates
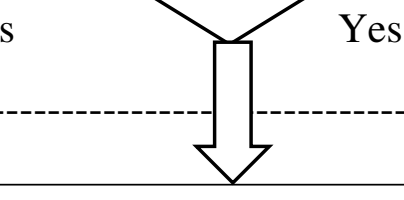

es

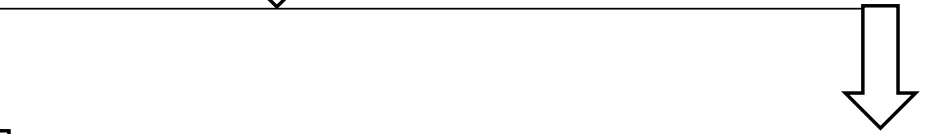

\section{Step 4: Test for Granger Causality}

Robustness Check

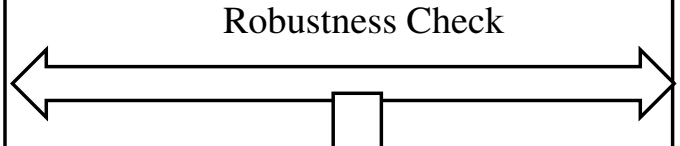

FMOLS, DOLS and CCR model 


\subsection{Unit root test}

302

303

304

305

306

307

308

309

310

311

312

313

314

315

316

317

318

319

320

321

322

323

324

The unit root test is done to check the stationary properties and to identify the order of integration of the variables under study. Unit root test of any time series data is essential to avoid spurious regression. Different co-integration techniques require prerequisite necessities of different order of integration of the series of variables i.e., Johansen-Juselius co-integration method demands for all the variables to be integrated of order I(1) (Gunes, 2009; Nasir and Rehman, 2011; Rej and Nag, 2018) and Autoregressive distributed lag model (ARDL) requires all the variables to be integrated of $\mathrm{I}(1)$ or mixture of both $\mathrm{I}(1) / \mathrm{I}(0)$ but not to be integrated of I(2) (Pal and Mitra, 2017; Mahmood et al., 2020).

In the present study, Augmented Dickey-Fuller (ADF) test and Phillips Perron (PP) unit root test are done in both level and first difference to find out the degree of integration of the variables under study. Many econometric studies have emphasized the advantage of Phillips Perron (PP) test over ADF test having high power to reject the null hypothesis of having unit root in the presence of structural breaks (Hamdi et al., 2015), correction of the serial correlation and time dependent heteroscedasticity in the lagged difference terms of the variables under study (Thangavelu and Rajaguru, 2004).

\subsection{Co- integration: ARDL Bounds testing approach}

There is plethora of literature over the past few decades which have proposed various popular residual based econometric co-integration techniques to establish long run relationship among variables like Granger (1981), Engle-Granger (1987), Johansen-Juselius (1990), Phillips and Hansen (1990) fully modified OLS estimation, Johansen (1996) and ARDL bound testing approach (2001). The autoregressive distributive lag (ARDL) bound testing approach proposed by Pesaran, Shin and Smith (2001) is preferred over other existing co-integration techniques due to the following advantages: firstly, ARDL is most appropriate for smaller sample size. 
Secondly, ARDL approach can be estimated irrespective of if the variables are stationary at level, integrated at first differences, or fractionally integrated. Thirdly, it can efficiently address the possible endogeneity issues of the explanatory variables in the model. Fourthly, consistency achieved in the estimations of both short run and long run parameters and finally, the ARDL approach allows different optimal lags associated with each of the variables which is not taken care in classical co-integration techniques.

In view of the above benefits and dealing with a data of smaller sample size of only 49 annual observations (1970-2018), we have employed the autoregressive distributive lag (ARDL) bound testing approach in equation (3) as follows:

$\Delta \ln C_{t}=\beta_{0}+\beta_{1} t+\beta_{2} \ln C_{t-1}+\beta_{3} \ln Y_{t-1}+\beta_{4} \ln Y_{t-1}^{2}+\beta_{5} \ln Y_{t-1}^{3}+\beta_{6} \ln R E C_{t-1}+$ $\beta_{7} \ln G C F_{t-1}+\beta_{8}\left(\ln R E C \times \ln G C F_{t-1}\right)+\sum_{j=1}^{k_{1}} \lambda_{1 j} \Delta \ln C_{t-j}+\sum_{j=0}^{k_{2}} \lambda_{2 j} \Delta \ln Y_{t-j}+$ $\sum_{j=0}^{k_{3}} \lambda_{3 j} \Delta \ln Y_{t-j}^{2}+\sum_{j=0}^{k_{4}} \lambda_{4 j} \Delta \ln Y_{t-j}^{3}+\sum_{j=0}^{k_{5}} \lambda_{5 j} \Delta \ln R E C_{t-j}+\sum_{j=0}^{k_{6}} \lambda_{6 j} \Delta \ln G C F_{t-j}+$ $\sum_{j=0}^{k_{7}} \lambda_{7 j} \Delta\left(\ln R E C \times \ln G C F_{t-j}\right)+\varepsilon_{1 t}$

Where $\Delta$ is the first difference operator, $\beta_{0}$ is the constant term, $\beta_{1}$ is the coefficient of trend component, $\beta_{2}-\beta_{8}$ are long run coefficients, $\lambda_{1 j}-\lambda_{7 j}$ are short run coefficients, $k_{1}-k_{7}$ are the lag lengths associated with each variable, $\varepsilon_{1 \mathrm{t}}$ is noise error term and nomenclature of variables is identical to the variables as defined in equation (2).

The ARDL bound test procedure can be done with the following steps: The first step is to choose the criteria for optimal lag length selection in the model. The Akaike Information Criteria (AIC) can be employed for optimal lag length selection. The second step is to find the existence of co-integration among the variables through administering F-statistics. The null hypothesis of no co-integration, $\mathrm{H}_{0}: \beta_{2}=\beta_{3}=\beta_{4}=\beta_{5}=\beta_{6}=\beta_{7}=\beta_{8}=0$ can be tested against the alternative hypothesis, $H_{1}: \beta_{2} \neq \beta_{3} \neq \beta_{4} \neq \beta_{5} \neq \beta_{6} \neq \beta_{7} \neq \beta_{8} \neq 0$. Two sets of critical $\mathrm{F}$ statistics were 
computed for larger sample size by Pesaran and Shin (1998) and Pesaran et al. (2001). One set of critical values (lower bounds) consider that all the concerned variables under study are stationary at level, whereas another set of critical values (upper bounds) consider that underlying variables are stationary at first difference. Narayan (2005) debated that critical values designed by Pesaran et al. (2001) may mislead the results for smaller sample size and consequently another two sets of critical F statistics, upper critical bounds and lower critical bounds for smaller sample size ranging from 30 to 80 sample observations were computed by Narayan (2005). In the ARDL bound testing framework, three possible situation can be derived after the estimation of ARDL model. The first is the co-integration situation if the computed F statistics is greater than the upper critical bounds value, then the null hypothesis of no cointegration can be rejected. The second possibility is the no co-integration situation when the estimated F statistics falls below the lower critical bounds value, then the null hypothesis of no co-integration cannot be rejected. Finally inconclusive situation is possible if the computed F statistics falls within upper and lower critical bounds value. In the present study, critical values designed by both Pesaran et al. (2001) and Narayan (2005) are utilized due to the small sample size. Further, the stability of ARDL bound testing can be performed through CUSUM and CUSUMQ test.

\subsection{Robustness test}

The robustness check of the ARDL bounds test of co-integration has been done with Bayer and Hanck's (2013) combined co-integration analysis and the robustness of the estimations of the ARDL model will be validated through the DOLS, FMOLS and CCR method.

\subsubsection{Bayer and Hanck (2013) combined co-integration analysis}

The findings from the traditional co-integration models are often biased because of the timeseries properties of the variables and insufficient sample size. Bayer and Hanck (2013) proposed the Bayer-Hanck combined test for non-co-integration, which overcomes the 
limitations of the traditional co-integration models while providing the efficient estimations in the presence of inadequate sample size. Furthermore, this procedure integrates the results of various traditional co-integration models and generalizes the results using a Fisher statistic based on the following specification:

$E G-J=-2[\ln (P(E G))+\ln (P(J))]$

$$
E G-J-B-B D M=-2[\ln (P(E G))+\ln (P(J))+\ln (P(B O))+\ln (P(B D M))]
$$

Where, P denotes the probability value of each test; EG-J denotes the $\mathrm{p}$ values of the Fisher statistic for the combined Engle-Granger (EG) and Johansen (J) tests; while EG-J-B-BDM denotes the $\mathrm{p}$ values of the Fisher statistic for the combined (Engle and Granger 1987; Johansen 1988; Boswijk 1994; Banerjee et al. 1998) tests. The statistical significance of the Fisher statistic is used to refute the null hypothesis of no co-integration.

\subsubsection{DOLS, FMOLS and CCR method}

Phillips and Hansen (1990) devised FMOLS to provide optimal estimates of co-integration regressions. Kernel estimators of the nuisance parameters that alter the asymptotic distribution of OLS estimator are used in this method. This technique adapts OLS to account for serial correlation effects, and checks for the endogeneity in the regressors that arise from the presence of co-integrating relationships in order to attain asymptotic efficiency.

Canonical Cointegrating Regression (CCR) designed by Park (1992) utilizes single cointegration equation to eliminate the long run dependence between the cointegration equation and the stochastic regressors innovations. CCR also eradicates the endogeneity caused by the long run correlation of cointegrating equation errors and the stochastic regressors innovations. 


\subsection{VECM Granger causality test}

397

If the variables are integrated of I(1) and existence of long run relationship can be confirmed from the estimations of ARDL bound testing procedure, we can move ahead to perform VECM

Granger causality test to examine the short run dynamic causal relationship among the underlying variables. The VECM model can be written in equations (6 - 12) as follows:

401

$\Delta \ln C_{t}=\phi_{0}+\sum_{i=1}^{j} \phi_{1 i} \Delta \ln C_{t-i}+\sum_{i=1}^{j} \phi_{2 i} \Delta \ln Y_{t-i}+\sum_{i=1}^{j} \phi_{3 i} \Delta \ln Y_{t-i}^{2}+$

402

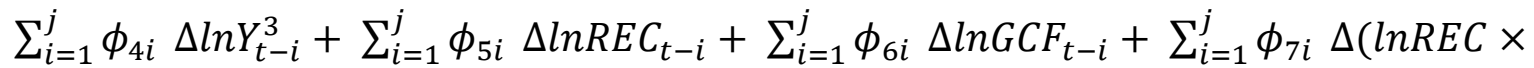

403

$\left.\ln G C F_{t-i}\right)+\Psi_{1} E C T_{t-1}+\mu_{1 t}$

404

$\Delta \ln Y_{t}=\theta_{0}+\sum_{i=1}^{j} \theta_{1 i} \Delta \ln Y_{t-i}+\sum_{i=1}^{j} \theta_{2 i} \Delta \ln C_{t-i}+\sum_{i=1}^{j} \theta_{3 i} \Delta \ln Y_{t-i}^{2}+$

405

$\sum_{i=1}^{j} \theta_{4 i} \Delta \ln Y_{t-i}^{3}+\sum_{i=1}^{j} \theta_{5 i} \Delta \ln R E C_{t-i}+\sum_{i=1}^{j} \theta_{6 i} \Delta \ln G C F_{t-i}+\sum_{i=1}^{j} \theta_{7 i} \Delta(\ln R E C \times$

406

$\left.\ln G C F_{t-i}\right)+\Psi_{2} E C T_{t-1}+\mu_{2 t}$

407

$\Delta \ln Y_{t}^{2}=\gamma_{0}+\sum_{i=1}^{j} \gamma_{1 i} \Delta \ln Y_{t-i}^{2}+\sum_{i=1}^{j} \gamma_{2 i} \Delta \ln C_{t-i}+\sum_{i=1}^{j} \gamma_{3 i} \Delta \ln Y_{t-i}+$

408

$\sum_{i=1}^{j} \gamma_{4 i} \Delta \ln Y_{t-i}^{3}+\sum_{i=1}^{j} \gamma_{5 i} \Delta \ln R E C_{t-i}+\sum_{i=1}^{j} \gamma_{6 i} \Delta \ln G C F_{t-i}+\sum_{i=1}^{j} \gamma_{7 i} \Delta(\ln R E C \times$

409

$\left.\ln G C F_{t-i}\right)+\Psi_{3} E C T_{t-1}+\mu_{3 t}$

$\Delta \ln Y_{t}^{3}=\pi_{0}+\sum_{i=1}^{j} \pi_{1 i} \Delta \ln Y_{t-i}^{3}+\sum_{i=1}^{j} \pi_{2 i} \Delta \ln C_{t-i}+\sum_{i=1}^{j} \pi_{3 i} \Delta \ln Y_{t-i}+$

411

$\sum_{i=1}^{j} \pi_{4 i} \Delta \ln Y_{t-i}^{2}+\sum_{i=1}^{j} \pi_{5 i} \Delta \ln R E C_{t-i}+\sum_{i=1}^{j} \pi_{6 i} \Delta \ln G C F_{t-i}+\sum_{i=1}^{j} \pi_{7 i} \Delta(\ln R E C \times$

412

$\left.\ln G C F_{t-i}\right)+\Psi_{4} E C T_{t-1}+\mu_{4 t}$

413

$\Delta \ln R E C_{t}=\sigma_{0}+\sum_{i=1}^{j} \sigma_{1 i} \Delta \ln R E C_{t-i}+\sum_{i=1}^{j} \sigma_{2 i} \Delta \ln C_{t-i}+\sum_{i=1}^{j} \sigma_{3 i} \Delta \ln Y_{t-i}+$

414 $\sum_{i=1}^{j} \sigma_{4 i} \Delta \ln Y_{t-i}^{2}+\sum_{i=1}^{j} \sigma_{5 i} \Delta \ln Y_{t-i}^{3}+\sum_{i=1}^{j} \sigma_{6 i} \Delta \ln G C F_{t-i}+\sum_{i=1}^{j} \sigma_{7 i} \Delta(\ln R E C \times$

415 $\left.\ln G C F_{t-i}\right)+\Psi_{5} E C T_{t-1}+\mu_{5 t}$ 


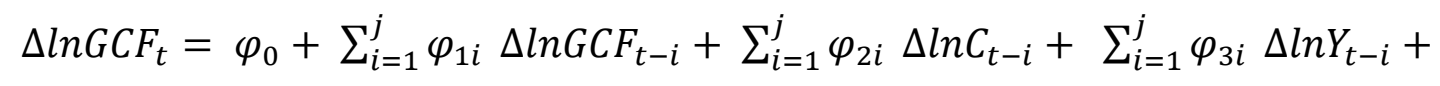

$417 \quad \sum_{i=1}^{j} \varphi_{4 i} \Delta \ln Y_{t-i}^{2}+\sum_{i=1}^{j} \varphi_{5 i} \Delta \ln Y_{t-i}^{3}+\sum_{i=1}^{j} \varphi_{6 i} \Delta \ln R E C_{t-i}+\sum_{i=1}^{j} \varphi_{7 i} \Delta(\ln R E C \times$

$\left.418 \quad \ln G C F_{t-i}\right)+\Psi_{6} E C T_{t-1}+\mu_{6 t}$

$\Delta\left(\ln R E C \times \ln G C F_{t}\right)=\Pi_{0}+\sum_{i=1}^{j} \Pi_{1 i} \Delta\left(\ln R E C \times \ln G C F_{t-i}\right)+\sum_{i=1}^{j} \Pi_{2 i} \Delta \ln C_{t-i}+$

422 Where $\Delta$ is the first difference operator, $\mu_{\mathrm{it}}$ are white noise error term. $\mathrm{ECT}_{\mathrm{t}-1}$ is the lagged error

423 correction term derived from the long run co-integrating relationship, i.e. residuals and represents the co-integrating vector. $\Psi_{\mathrm{j}}$ represent the adjustment coefficients which measure the speed of convergence from one period to next period towards short run to long run equilibrium pathway in response to impulse shocks to the system. $\mathrm{ECT}_{\mathrm{t}-1}$ should be negative and statistically significant to validate the long run causal relationship among the underlying variables in the model. Short run causality can be performed through statistical significance of joint $\mathrm{F}$ statistics of the coefficients of lagged value of exogenous variables. The appropriate criteria for optimal lag length selection of the restricted VAR model can be done through the lowest value of AIC, SIC and HQ statistics of the unrestricted VAR model.

\section{Results and discussions}

\subsection{Unit root test results}

Table 1 reports the results of unit root test by employing ADF and PP test to examine the order of integration among the underlying variables considered for present study. The result tabulated in Table 1 reveals that, the null hypothesis of unit root test (i.e., non-stationary) is accepted for all the variables at level. As the variables are converted into first difference, the null hypothesis 
439 integrated of order I(1).

Table 1: Unit Root test

\begin{tabular}{|c|c|c|c|c|c|c|}
\hline \multirow[b]{2}{*}{ Variables } & \multirow[b]{2}{*}{ Form } & \multicolumn{2}{|c|}{ ADF (t-statistics) } & \multicolumn{2}{|c|}{ PP (t-statistics) } & \multirow{2}{*}{$\begin{array}{c}\text { Order of } \\
\text { Integration }\end{array}$} \\
\hline & & Intercept & $\begin{array}{c}\text { Trend + } \\
\text { Intercept }\end{array}$ & Intercept & $\begin{array}{c}\text { Trend + } \\
\text { Intercept }\end{array}$ & \\
\hline \multirow[t]{2}{*}{$\ln C$} & Level & $\begin{array}{c}0.24 \\
(0.972)\end{array}$ & $\begin{array}{c}-2.41 \\
(0.375)\end{array}$ & $\begin{array}{c}0.27 \\
(0.974)\end{array}$ & $\begin{array}{c}-2.55 \\
(0.303)\end{array}$ & \multirow[t]{2}{*}{$\mathrm{I}(1)$} \\
\hline & $\begin{array}{l}\text { First } \\
\text { Difference }\end{array}$ & $\begin{array}{c}-7.32^{\text {**** }} \\
(0.000)\end{array}$ & $\begin{array}{c}-7.27^{* * * *} \\
(0.000)\end{array}$ & $\begin{array}{c}-7.31^{* * * *} \\
(0.000)\end{array}$ & $\begin{array}{c}-7.26^{* * *} \\
(0.000)\end{array}$ & \\
\hline \multirow[t]{2}{*}{$\ln Y$} & Level & $\begin{array}{c}4.28 \\
(1.000)\end{array}$ & $\begin{array}{c}-1.69 \\
(0.741)\end{array}$ & $\begin{array}{c}5.25 \\
(1.000)\end{array}$ & $\begin{array}{c}-1.98 \\
(0.596)\end{array}$ & \multirow[t]{2}{*}{$\mathrm{I}(1)$} \\
\hline & $\begin{array}{l}\text { First } \\
\text { Difference }\end{array}$ & $\begin{array}{c}-5.71^{* * * *} \\
(0.000)\end{array}$ & $\begin{array}{l}-8.33^{* * * *} \\
(0.000)\end{array}$ & $\begin{array}{c}-5.78^{* * * *} \\
(0.000)\end{array}$ & $\begin{array}{c}-11.91^{* * *} \\
(0.000)\end{array}$ & \\
\hline \multirow[t]{2}{*}{$\ln Y^{2}$} & Level & $\begin{array}{c}5.35 \\
(1.000)\end{array}$ & $\begin{array}{c}-1.01 \\
(0.933)\end{array}$ & $\begin{array}{c}7.47 \\
(1.000)\end{array}$ & $\begin{array}{c}-1.01 \\
(0.932)\end{array}$ & \multirow[t]{2}{*}{$\mathrm{I}(1)$} \\
\hline & $\begin{array}{l}\text { First } \\
\text { Difference }\end{array}$ & $\begin{array}{c}-5.01^{* * * *} \\
(0.000)\end{array}$ & $\begin{array}{l}-8.26^{* * * *} \\
(0.000)\end{array}$ & $\begin{array}{l}-5.11^{* * *} \\
(0.000)\end{array}$ & $\begin{array}{c}-12.70^{* * *} \\
(0.000)\end{array}$ & \\
\hline \multirow[t]{2}{*}{$\ln Y^{3}$} & Level & $\begin{array}{c}6.57 \\
(1.000)\end{array}$ & $\begin{array}{c}-0.26 \\
(0.989)\end{array}$ & $\begin{array}{c}9.92 \\
(1.000)\end{array}$ & $\begin{array}{c}0.30 \\
(0.998)\end{array}$ & \multirow[t]{2}{*}{$\mathrm{I}(1)$} \\
\hline & $\begin{array}{l}\text { First } \\
\text { Difference }\end{array}$ & $\begin{array}{l}-4.33^{* * * *} \\
(0.001)\end{array}$ & $\begin{array}{c}-8.04^{* * * *} \\
(0.000)\end{array}$ & $\begin{array}{c}-4.39^{* * * *} \\
(0.001)\end{array}$ & $\begin{array}{c}-11.79^{* * * *} \\
(0.000)\end{array}$ & \\
\hline \multirow[t]{2}{*}{$\ln R E C$} & Level & $\begin{array}{c}0.28 \\
(0.975)\end{array}$ & $\begin{array}{c}-1.22 \\
(0.895)\end{array}$ & $\begin{array}{c}0.21 \\
(0.971)\end{array}$ & $\begin{array}{c}-1.33 \\
(0.867)\end{array}$ & \multirow[t]{2}{*}{$\mathrm{I}(1)$} \\
\hline & $\begin{array}{l}\text { First } \\
\text { Difference }\end{array}$ & $\begin{array}{l}-6.22^{* * * *} \\
(0.000)\end{array}$ & $\begin{array}{c}-6.36^{* * *} \\
(0.000)\end{array}$ & $\begin{array}{l}-6.22^{* * * *} \\
(0.000)\end{array}$ & $\begin{array}{c}-6.36^{* * * *} \\
(0.000)\end{array}$ & \\
\hline \multirow[t]{2}{*}{$\operatorname{lnGCF}$} & Level & $\begin{array}{c}0.72 \\
(0.991)\end{array}$ & $\begin{array}{c}-2.12 \\
(0.523)\end{array}$ & $\begin{array}{c}1.05 \\
(0.997)\end{array}$ & $\begin{array}{c}-1.99 \\
(0.589)\end{array}$ & \multirow[t]{2}{*}{$\mathrm{I}(1)$} \\
\hline & $\begin{array}{l}\text { First } \\
\text { Difference }\end{array}$ & $\begin{array}{c}-7.77^{* * * *} \\
(0.000)\end{array}$ & $\begin{array}{c}-8.03^{* * * *} \\
(0.000)\end{array}$ & $\begin{array}{c}-7.74^{* * * *} \\
(0.000)\end{array}$ & $\begin{array}{c}-8.18^{* * * *} \\
(0.000)\end{array}$ & \\
\hline \multirow[t]{2}{*}{$\operatorname{lnREC}{ }^{*} \ln \mathrm{GCF}$} & Level & $\begin{array}{c}-1.56 \\
(0.497)\end{array}$ & $\begin{array}{c}-1.31 \\
(0.873)\end{array}$ & $\begin{array}{c}-1.59 \\
(0.479)\end{array}$ & $\begin{array}{c}-1.23 \\
(0.894)\end{array}$ & \multirow[t]{2}{*}{$\mathrm{I}(1)$} \\
\hline & $\begin{array}{l}\text { First } \\
\text { Difference }\end{array}$ & $\begin{array}{c}-7.41^{* * * *} \\
(0.000)\end{array}$ & $\begin{array}{c}-7.49^{* * * *} \\
(0.000)\end{array}$ & $\begin{array}{c}-7.41^{* * * *} \\
(0.000)\end{array}$ & $\begin{array}{c}-7.49^{* * *} \\
(0.000)\end{array}$ & \\
\hline
\end{tabular}

441 Note: $* * *$ denotes a $1 \%$ level of significance, $* *$ denotes a $5 \%$ level of significance, $*$ denotes a $10 \%$ 442 level of significance.

\subsubsection{ARDL bounds test of co-integration result}

444 After confirming the stationarity level of underlying variables, the long run relationship among 445 the underlying variables is explored through ARDL bound testing approach. Akaike 446 Information Criteria (AIC) is utilized to identify the optimal lag order of Eq. (3) as AIC offers 447 reliable and efficient estimates to capture the long run dynamic relationship. After identifying 
the optimal lag order, bound test F-statistics is calculated as shown in Table 2. Table 2 reveals that the estimated bound test F-statistics exceeds the upper bound critical values designed by both Pesaran et al. (2001) and Narayan (2005) at 1\% level of significance. This strongly suggests that we can reject the null hypothesis of no co-integration against the alternative hypothesis of existence of co-integration among the underlying variables and conforming the existence of long run relationship among $\mathrm{CO}_{2}$ emissions, economic growth along with its square and cube term, renewable energy consumption, gross capital formation and the interaction term between renewable energy consumption and gross capital formation in case of India over the time period of 1970-2018.

Table 2: Bound F- test for co-integration

\begin{tabular}{|c|c|}
\hline Estimated model & $\ln C=f\left(\ln Y, \ln Y^{2}, \ln Y^{3}, \ln R E C, \operatorname{lnGCF}, \ln R E C^{*} \ln G C F\right)$ \\
\hline $\begin{array}{l}\text { Bound test F- } \\
\text { statistics }\end{array}$ & $8.105^{* * * *}$ \\
\hline $\begin{array}{l}\text { Optimal lag } \\
\text { length }\end{array}$ & $2,2,2,2,1,2,1$ \\
\hline & Narayan (2005) \\
\hline
\end{tabular}

Note: $* * *$ denotes a $1 \%$ level of significance, $* *$ denotes a $5 \%$ level of significance, $*$ denotes a $10 \%$ level of significance.

\subsubsection{ARDL results}

Table 3 demonstrates the long run coefficient estimates of the underlying variables in the

ARDL model of Eq. (3) and reveals that the estimated long run coefficients of per capita GDP, square of per capita GDP and cube of per capita GDP are positive, negative and positive respectively and significant at $1 \%$ level of significance. This supports the existence of $\mathrm{N}$-shape EKC for India. Our findings is in the line with the empirical findings of existence of $\mathrm{N}$ shaped EKC phenomenon by Pal and Mitra (2017) for India and China, Allard et al. (2018) for lower

467 middle and high income countries, Menéndez et al. (2014) for 27 countries of the European Union. 
The turnaround points of the $\mathrm{N}$-shaped EKC are found to fall within the sample range and estimated at per capita GDP of USD 643.2 in 1995 and USD 1437.9 in 2012. This indicates that India attained a peak in the EKC at early stage of economic growth where it reached the positive peak in the year 1995 and then reached the lowest point of turnaround in the year 2012 .

The peak in 1995 and subsequent decline in emissions could have been a result of economic liberalization which led to privatization of major part of the energy sector and adoption of energy efficient technologies and emphasis on conservation as energy demand was also growing. This period also saw the beginning of the information technology boom in India and the gradual shift of the economy towards the service sector. The Indian software sector saw a compound annual growth of about 52\% between 1991 and 1996 which seems to have had a direct impact on a downturn in emissions with respect to income in 1995. An upturn in $\mathrm{CO}_{2}$ emissions after 2012 could be attributable to multiple factors like the Government of India policies attracting FDI inflow and infusion of capital investment in the energy intensive manufacturing sector of India. While the world economy was facing a economic slowdown after the financial crisis of 2009 , in $2011-12$, FDI in India rose 34.4 per cent to $\$ 46.84$ billion, compared with $\$ 34.84$ billion in the previous year. India's growth rate was forecasted to around $9 \%$ and India emerged as one of the most favoured destinations for investment. Also, India witnessed a stagnation of service sector as a share of overall GDP during the period 2008-11 with $0.03 \%$ average annual negative growth rate over the same timeline. This may have also contributed to rising emissions with GDP around 2012.

The result tabulated in Table 3 postulates that the impact of renewable energy consumption on $\mathrm{CO}_{2}$ emissions is found to be negative and significant at $1 \%$ level of significance indicating that $1 \%$ increase in consumption of renewable energy can reduce the $\mathrm{CO}_{2}$ emission by $3.7 \%$ aiding the INDC commitment undertaken by the Government of India in 2015 to reduce carbon emission intensity of its GDP by 33-35\% by 2030 from 2005 through policy measures of 
enhancing the share of renewable energy sources to $40 \%$ in total installed capacity by 2030 (MoEFCC, 2015).

496

497

498

499

500

501

502

503

504

505

506

507

508

509

510

511

512

The impact of gross capital formation on $\mathrm{CO}_{2}$ emissions is found to be positive and significant at $1 \%$ level of significance. $1 \%$ increase of gross capital formation is found to be associated with $2.2 \%$ increase of $\mathrm{CO}_{2}$ emissions for India. This finding is similar to Rahman and Ahmad (2018) findings for Pakistan that reported positive and significant impact of gross capital formation on $\mathrm{CO}_{2}$ emission due to capital investment heavily associated with emission intensive industrial and transportation sector. Economic survey (2019-20) postulates that India has witnessed a steady growth of gross capital formation in both private and public sector by $11.8 \%$ and $16.6 \%$ respectively in the fiscal year of $2107-18$ compared to previous year. The capital formation was channelized through energy intensive manufacturing sector to revive the domestic manufacturing capacity as an integral part of 'Make in India' platform resulting in rise in emissions in India. The interaction term between renewable energy consumption and gross capital formation is also found to be positive and significant at $1 \%$ level of significance. The result suggests that gross capital formation in India may have nullified the beneficial effect of renewable energy consumption on environmental quality in the long run.

Table 3: Long run coefficient estimates

\begin{tabular}{|l|c|c|c|}
\hline Variables & Co-efficient & t-statistics & Prob. \\
\hline $\ln \mathrm{Y}$ & $118.92^{* * *}$ & 3.44 & 0.002 \\
\hline $\ln \mathrm{Y}^{2}$ & $-17.37^{* * *}$ & -3.33 & 0.003 \\
\hline $\ln \mathrm{Y}^{3}$ & $0.84^{* * *}$ & 3.21 & 0.003 \\
\hline $\ln \mathrm{REC}$ & $-3.67^{* * *}$ & -3.03 & 0.005 \\
\hline $\operatorname{lnGCF}$ & $2.22^{* * *}$ & 3.67 & 0.001 \\
\hline $\ln \mathrm{REC}{ }^{*} \operatorname{lnGCF}$ & $0.41^{* * *}$ & 3.01 & 0.006 \\
\hline Shape of the EKC & 'N'-Shaped & \\
\hline Turnaround Points & Year: 1995 (\$643.4), Year: 2012 (\$1437.9) \\
\hline Inflection Point & Year: 2004 (\$962.1) \\
\cline { 1 - 3 }
\end{tabular}

Note: $* * *$ denotes a $1 \%$ level of significance. Turnaround points and Inflection point have been calculated as per Lorente and Herranz (2016). 
513 The short run dynamics as tabulated in Table 4 postulates that none of the coefficients of GDP,

514 and its square and cube term are significant in the short run. The error correction term (ECT)

515 in Eq. (3) is found to be negative and significant at $1 \%$ level of significance implying that time

516 series will have convergence in long run equilibrium and the error is corrected from one period

517 to next period towards short run to long run equilibrium pathway at a rate of around $42.7 \%$. $\mathrm{R}^{2}$

518 value for the ARDL model is moderately high i.e., $71.4 \%$ inferring the model has quite good

519 fit and $71.4 \%$ of variability in the endogenous variable is explained by the exogenous variables.

$520 \mathrm{R}^{2}$ value in equation (3) is less than Durbin-Watson (D/W) statistics indicating that the

521 estimations do not exhibit spurious regression.

522 Table 4: Short run estimates

\begin{tabular}{|c|c|c|c|}
\hline Variables & Co-efficient & t-statistics & Prob. \\
\hline$\Delta\left(\ln Y_{t}\right)$ & -7.13 & -0.19 & 0.85 \\
\hline$\Delta\left(\ln Y_{t-1}\right)$ & $-108.24^{* * *}$ & -2.92 & 0.01 \\
\hline$\Delta\left(\ln Y_{t}\right)^{2}$ & 1.46 & 0.25 & 0.80 \\
\hline$\Delta\left(\ln Y_{t-1}\right)^{2}$ & $16.97^{* * *}$ & 2.95 & 0.01 \\
\hline$\Delta\left(\ln Y_{t}\right)^{3}$ & -0.09 & -0.31 & 0.76 \\
\hline$\Delta\left(\ln Y_{t-1}\right)^{3}$ & $-0.88^{* * *}$ & -2.98 & 0.01 \\
\hline$\Delta\left(\operatorname{lnREC} C_{t}\right)$ & -0.70 & -1.59 & 0.12 \\
\hline$\left.\Delta(\operatorname{lnGCF})_{t}\right)$ & 0.32 & 1.59 & 0.12 \\
\hline$\Delta\left(\ln \mathrm{GCF}_{\mathrm{t}-1}\right)$ & $-0.16^{* * *}$ & -3.62 & 0.00 \\
\hline$\Delta\left(\operatorname{lnREC}_{t}{ }^{*} \ln \mathrm{GCF}_{\mathrm{t}}\right)$ & 0.07 & 1.52 & 0.14 \\
\hline Constant & $-124.08^{* * *}$ & -8.33 & 0.00 \\
\hline Trend & 0.001 & 1.65 & 0.11 \\
\hline ECT (-1) & $-0.427^{* * *}$ & -8.33 & 0.00 \\
\hline $\mathrm{R}^{2}$ & \multirow{4}{*}{\multicolumn{3}{|c|}{$\begin{array}{l}0.714 \\
0.602 \\
6.35^{* * *}[0.000] \\
2.09\end{array}$}} \\
\hline Adjusted $\mathrm{R}^{2}$ & & & \\
\hline F- Statistics [Prob.] & & & \\
\hline D/W Statistics & & & \\
\hline
\end{tabular}

523 Note: $* * *$ denotes a $1 \%$ level of significance, $* *$ denotes a $5 \%$ level of significance, $*$ denotes a $10 \%$ 524 level of significance.

525 Table 5 demonstrates the diagnostic test statistics of the estimated ARDL model and confirms

526 that the model passes all the diagnostic tests i.e., Breusch-Godfrey serial correlation LM test,

527 ARCH test, Ramsey RESET test (functional form misspecification) and Jarque-Bera test of

528 normality. The underlying ARDL model is also passed through stability test as reflected in

529 Cumulative Sum of Recursive Residual (CUSUM) and Cumulative Sum of Squares of 
530 Recursive Residual (CUSUMQ) test (Figures 2 and 3). The dotted straight lines in both the

531 figures indicate the critical limit at 5\% level of significance. In the figures, since the plots of 532 both CUSUM and CUSUMQ statistics are well within the critical limit, it can be concluded 533 that the stability of all the coefficients of the ARDL model is achieved.

534 Table 5: Diagnostic tests for the ARDL model

\begin{tabular}{|l|c|c|c|}
\hline Diagnostic test & Null hypothesis & Statistics & Inference \\
\hline Jarque-Bera test & $\begin{array}{c}\mathrm{H}_{0}: \text { Normal distribution } \\
\text { of error terms }\end{array}$ & $\begin{array}{c}\chi^{2}: 1.049 \\
\text { Prob: } 0.592\end{array}$ & $\begin{array}{c}\text { Error terms are } \\
\text { normally distributed }\end{array}$ \\
\hline $\begin{array}{l}\text { Breusch-Godfrey } \\
\text { serial correlation } \\
\text { LM test }\end{array}$ & $\mathrm{H}_{0}$ : No auto correlation & $\begin{array}{c}\mathrm{F}(2): 1.372 \\
\text { Prob: } 0.272\end{array}$ & No serial correlation \\
\hline ARCH test & $\mathrm{H}_{0}:$ Homoskedasticity & $\begin{array}{c}\mathrm{F}(2): 0.296 \\
\text { Prob: } 0.745\end{array}$ & No heteroskedasticity \\
\hline Ramsey RESET test & $\begin{array}{c}\text { Ho: Model specification } \\
\text { is correct }\end{array}$ & $\begin{array}{c}\mathrm{F}(1): 0.063 \\
\text { Prob: } 0.804\end{array}$ & $\begin{array}{c}\text { Model is correctly } \\
\text { specified }\end{array}$ \\
\hline
\end{tabular}

535

536 Figure 2: Plot of CUSUM test

15

10

537

CUSUM

5\% Significance

538

539 
0.8

0.6

0.4

0.2

0.0

$-0.2$

$-0.4$

$\begin{array}{llllllllllll}96 & 98 & 00 & 02 & 04 & 06 & 08 & 10 & 12 & 14 & 16 & 18\end{array}$

\section{$543 \quad 6.3$ Results of the robustness test}

544 Robustness of the ARDL bounds test of co-integration has further been tested with Bayer and

545 Hanck (2013) combined co-integration analysis and the result is presented in table 6. In table

546 6, Fisher statistics of both the EG-JOH and the EG-J-BO-BDM are found to be significant at $5475 \%$ level of significance, thereby suggesting the co-integrating relationship among the underlying variables and validating the estimations of ARDL bounds test of co-integration.

Table 6: Results for Combined Co-integration test by Bayer-Hanck (2013)

\begin{tabular}{|c|c|c|c|c|c|}
\hline Estimated Model & \multicolumn{5}{|c|}{$\ln C=f\left(\ln Y, \ln Y^{2}, \ln Y^{3}, \ln R E C, \ln G C F, \ln R E C^{*} \ln G C F\right)$} \\
\hline Fisher Type & Test Statistics & CV@1\% & CV@5\% & CV@10\% & Decision \\
\hline EG-JOH & $14.068 * *$ & 15.35 & 10.35 & 8.2 & Co-integrated \\
\hline EG-J-BO-BDM & $77.812 * * *$ & 29.54 & 19.76 & 15.75 & Co-integrated \\
\hline
\end{tabular}

Note: $* * * * *$ and $*$ indicate the results are significant at the 1,5 , and $10 \%$ level, respectively.

549 Further, alternative co-integration techniques i.e., fully modified OLS, dynamic OLS and

550 Canonical co-integration regression techniques are employed in our present study for

551 robustness checking of the estimated ARDL model. The result tabulated in table 7 postulates

552 the $\mathrm{N}$-shape EKC relationship between $\mathrm{CO}_{2}$ emissions and economic growth. The findings of

553 FMOLS, DOLS and CCR is consistent with the ARDL estimations. 
Table 7: Results of FMOLS, DOLS and CCR

\begin{tabular}{|l|c|c|c|c|c|c|}
\hline \multirow{2}{*}{ Variable } & \multicolumn{2}{|c|}{ FMOLS } & \multicolumn{2}{c|}{ DOLS } & \multicolumn{2}{c|}{ CCR } \\
\cline { 2 - 7 } & Coefficient & Prob. & Coefficient & Prob. & Coefficient & Prob. \\
\hline $\ln \mathrm{Y}$ & $56.03^{* *}$ & 0.02 & $89.08^{* * *}$ & 0.00 & $57.56^{* *}$ & 0.03 \\
\hline $\ln \mathrm{Y}^{2}$ & $-7.61^{* *}$ & 0.03 & $-12.75^{* * *}$ & 0.00 & $-7.85^{* *}$ & 0.05 \\
\hline $\ln \mathrm{Y}^{3}$ & $0.33^{* *}$ & 0.04 & $0.61^{* * *}$ & 0.00 & $0.35^{*}$ & 0.07 \\
\hline $\ln \mathrm{REC}$ & $-3.03^{* * *}$ & 0.00 & $-5.71^{* * *}$ & 0.00 & $-2.97^{* * *}$ & 0.00 \\
\hline $\operatorname{lnGCF}$ & $1.45^{* * *}$ & 0.00 & $2.66^{* * *}$ & 0.00 & $1.43^{* * *}$ & 0.00 \\
\hline $\ln \mathrm{REC}{ }^{*} \operatorname{lnGCF}$ & $0.36^{* * *}$ & 0.00 & $0.65^{* * *}$ & 0.00 & $0.35^{* * *}$ & 0.00 \\
\hline
\end{tabular}

Note: $* * *$ denotes a $1 \%$ level of significance, $* *$ denotes a $5 \%$ level of significance, $*$ denotes a $10 \%$

556 level of significance.

\section{6.4 VECM Granger causality test results}

Table 8 reports the result of VECM Granger causality analysis. The error correction term in

Eq. (4) is found to be negative and significant at $1 \%$ level of significance indicating the long run relationship among the underlying variables in Eq.(4) and also validating the estimations of ARDL model of Eq. (3). According to table 9, there exists unidirectional short run causality from: (1) GDP to $\mathrm{CO}_{2}$; (2) (2) Square of GDP to $\mathrm{CO}_{2}$;

(3) Cube of GDP to $\mathrm{CO}_{2}$;

(4) Renewable energy consumption to $\mathrm{CO}_{2}$; (5) Interaction term between RE consumption and gross capital formation to $\mathrm{CO}_{2}$; (6) $\mathrm{RE}$ consumption to GDP; and (7) Interaction term between $\mathrm{RE}$ consumption and gross capital formation to GDP. The short run linkages are summarized in figure 4. Fig. 4 shows that RE consumption and the interaction term between RE consumption and gross capital formation not only have direct impact on $\mathrm{CO}_{2}$ emission but also have indirect influence on $\mathrm{CO}_{2}$ emission through the channel of economic growth in short run. 
574 Table 8: Results of VECM Granger causality test

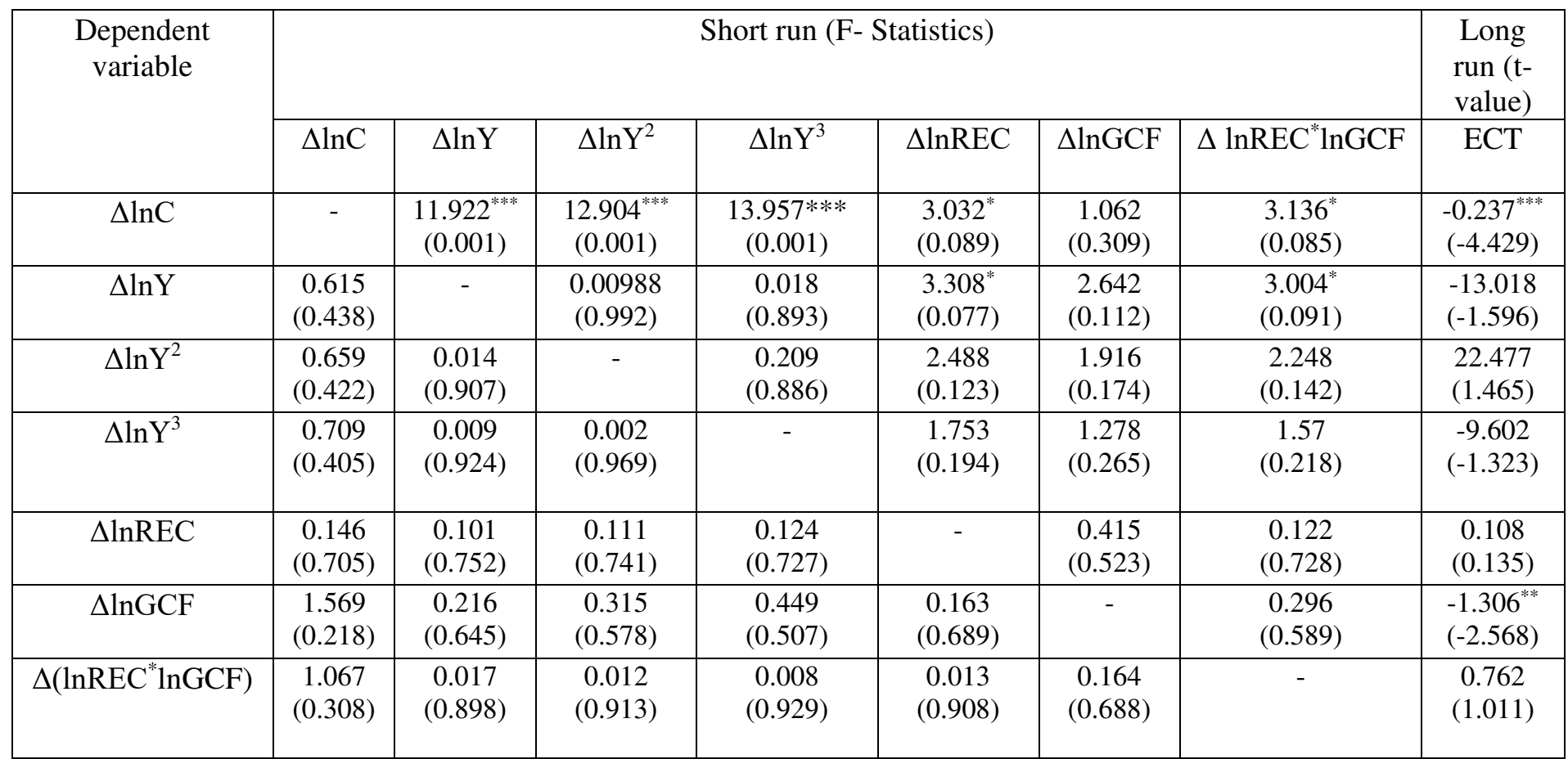

$575 * * *$ denotes a $1 \%$ level of significance, $* *$ denotes a $5 \%$ level of significance, $*$ denotes a $10 \%$ level of 576 significance. The optimal lag length $\mathrm{j}=1$ is selected through the lowest value of AIC, SIC and HQ 577 statistics of the unrestricted VAR model.

578 Figure 4: Short run linkages summarized from Granger Causality. Note: $\mathrm{X} \longrightarrow \mathrm{Y}$ indicates 579 changes in X Granger causes changes in Y.

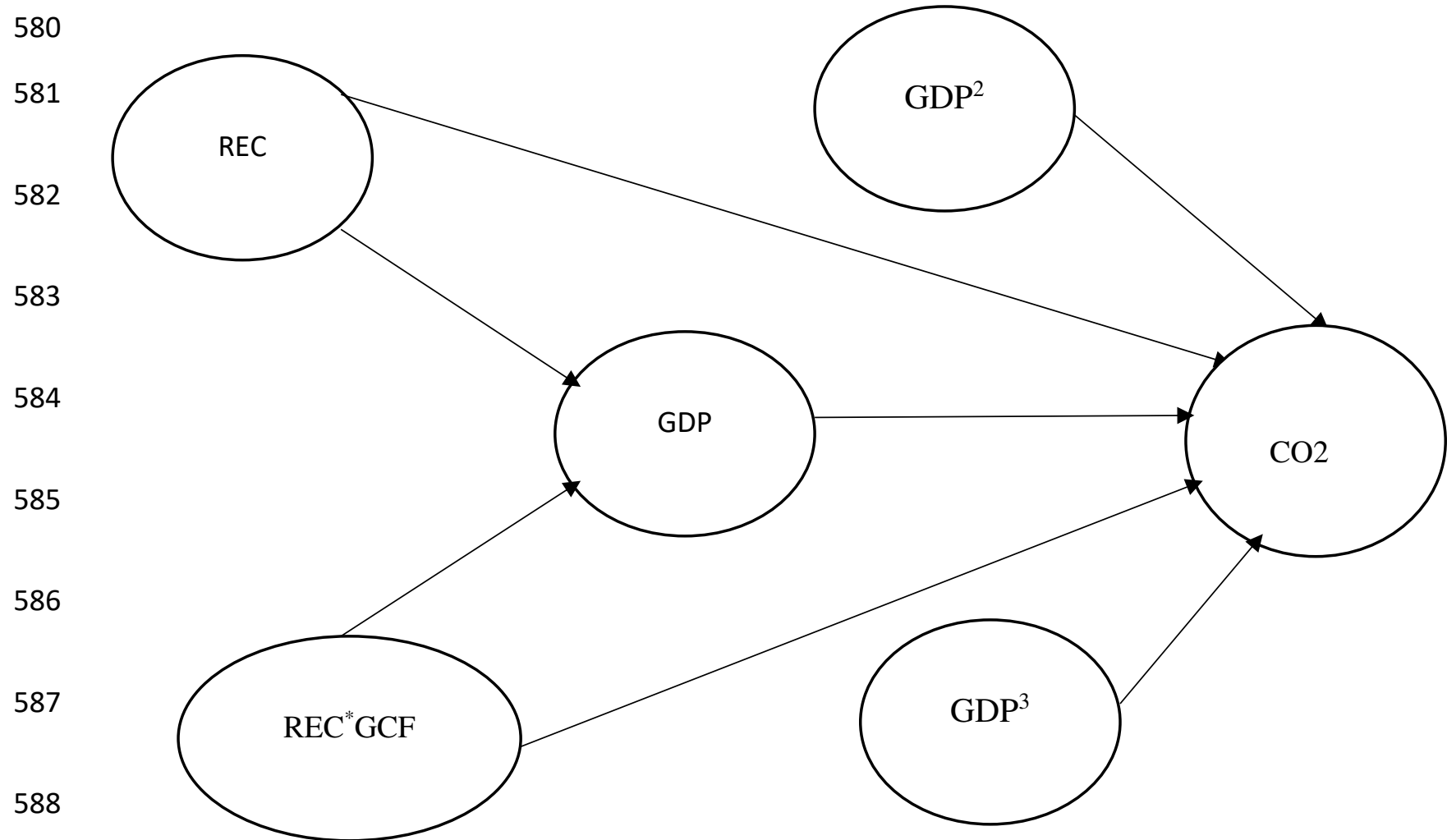




\section{Conclusion and policy implications}

590

591

592

593

594

595

596

597

598

599

600

601

602

603

604

605

606

607

608

609

610

611

612

613

The objective of this study is three-fold: first, to examine the long run association between economic growth, $\mathrm{CO}_{2}$ emissions, renewable energy consumption (RE), gross capital formation and the interaction term between RE and gross capital formation in the EKC framework for India for the period 1970-2018 by employing ARDL bounds test of cointegration. Secondly to investigate the existence of EKC hypothesis for India and to determine the shape of the EKC and finally to determine if capital formation has been conducive for penetration of renewable energy development in the pathway of decarbonizing Indian economy. The findings of this empirical investigations not only establishes the long run relationship among the underlying variables but also provide strong evidence of $\mathrm{N}$ shaped relationship between economic growth and $\mathrm{CO}_{2}$ emissions for India in the long run. The $\mathrm{N}$ shape EKC implies that initially $\mathrm{CO} 2$ emissions increase with economic growth, and then after having reached a peak in the year 1995 starts reducing with expansion of the economy. With further economic development emissions again start rising after plunging at a minimum in the year 2012. Both the downturn and upturns can be explained by policy reforms of the government and the role of the service sector in the national economy. The findings suggest that the present trend in economic growth policy driven by emphasis on manufacturing sector may be currently pushing India up along the upward arm of a $\mathrm{N}$ shaped the EKC. Hence, to have a more sustainable growth trade and FDI policies need to be redesigned in order to attain a downturn of the $\mathrm{N}$ shaped $\mathrm{EKC}$ in India near future. For this it is important to look at the impact of RE and capital formation on emissions and economic growth.

The empirical results show that $\mathrm{RE}$ consumption has reduced $\mathrm{CO} 2$ emissions in the long run and $1 \%$ expansion of $\mathrm{RE}$ consumption is associated with $3.7 \%$ reduction of $\mathrm{CO}_{2}$ emissions. This finding supports the INDC commitment of India to reduce emissions through installation of $175 \mathrm{GW}$ renewable electricity capacity by 2022 and increasing the share of RE alternatives 

interaction term of $\mathrm{RE}$ consumption and gross capital formation has been found to be significant in influencing $\mathrm{CO} 2$ emissions. The coefficient has been found to be positive for the data period, implying that the capital formation has not supplemented the RE use in the period of analysis. Propagation of RE alternatives in India continues to face serious policy challenges in the form of high fixed cost and maintenance cost, low reliability, and enormous land requirement for setting up of the new RE projects (Rej and Nag, 2021). Renewable energy sector of India requires huge quantum of capital investment of Rs. 5 to 6 trillion for enhancing the additional renewable capacity addition of $106 \mathrm{GW}$ over the fiscal year 2018-2022 along with additional post investments to connect the renewables to the Grid (Srikanth, 2018) while the capital formation is likely to be grown by only around USD 205 billion in renewables over the same timeline suggesting a huge shortfall in the capital formation in renewable energy development of India. Our results imply that higher RE friendly investments in total capital formation may help in reducing emissions. The Government of India has undertaken alternate action plans to promote renewables by supporting a lower Goods and Services Tax (GST) rate of $5 \%$ for production of renewable energy devices while for inputs to thermal generation the rate of GST levied varying between $5 \%$ to $18 \%$ and providing subsidy on the tariff of renewable electricity consumption over USD 2.2 billion in 2017 (IEA, 2020). Foreign Direct Investment in the RE sector may bring in capital and advanced technology with easier FDI norms.

In addition, the long run outcome of per capita gross capital formation is found to have significant and positive impact on $\mathrm{CO}_{2}$ emissions which demands for proper attention in designing the robust energy policy framework to mitigate the detrimental effect of carbon emissions while undertaking the holistic approach to integrate the capital investment in domestic manufacturing. Strengthening the environmental regulations, deploying more capital formation in $\mathrm{R} \& \mathrm{D}$ for invention and adoption of advanced energy efficient technologies, 
imposing carbon tax and formation of green climate fund could be recommended for India to integrate in its sustainable design of future energy policy.

641 Looking at the short run result, there exists unidirectional short run Granger causality from per 642 capita RE consumption to per capita GDP suggesting the evidence of growth hypothesis for 643 India in short run. Further, the evidence of short run unidirectional Granger causality from per capita GDP to per capita $\mathrm{CO}_{2}$ emissions suggest that policy planning for reduction of carbon emissions need to be done through adoption of energy efficiency measures and incentivised capital investment in environment friendly green technologies which is also evidenced through the unidirectional short run causality from the interaction term between per capita RE consumption and per capita gross capital formation to GDP per capita. The absence of Granger causality from $\mathrm{CO}_{2}$ emissions to economic growth implies that India can control its $\mathrm{CO}_{2}$ emissions without affecting economic growth.

To conclude, our study indicates that based on past 49 years of data, India may have experienced an $\mathrm{N}$ shaped environmental Kuznets curve and is currently climbing up the third arm of the N. Present policy thrust on the manufacturing sector, increased investment in energy intensive technologies and production, disassociation between capital formation in the economy and capital requirement in the renewable sector may make it difficult for India to achieve a possible downturn in emissions with economic growth in the near future. In spite of India's energy policy emphasis on renewables, achieving a target reduction in emissions will be possible only if investment or capital formation in the economy is complementary to penetration and increased usage of renewables. Adoption and implementation of certain measures like standardization of pollution standards, mandating strict energy efficiency standards, and extensive capital investments in not only renewable energy generation but also in ensuring a low cost but steady and reliable clean power generation, setting up advanced and modernized grid transmission and distribution and heightening more capital investments in 
energy related research may reinforce the alternate policy directions to improve the climate change and aiding India to achieve the target reduction of emissions in the INDC commitment by 2030 .

\section{Declarations:}

-Ethical Approval: Not applicable

-Consent to Participate: Not applicable

-Consent to Publish: Not applicable

-Funding: No funding was received for this study.

-Competing Interests: The authors declare that they have no competing interests.

-Availability of data and materials: The sources of the data used in this study are duly mentioned.

\section{Authors' Contributions:}

Soumen Rej: Conceptualization, Methodology, Software, Data collection, Writing- preparing original draft, Investigation, Validation.

Barnali Nag: Conceptualization, Methodology, Supervision, Software, Writing- reviewing and editing, Investigation, Validation.

\section{Reference}

Ahmed, A., Uddin, G.S., \& Sohag, K. (2016). Biomass energy, technological progress and the Environmental Kuznets Curve: Evidence from selected European countries. Biomass and Bioenergy 90, 202-208.

Ahmed, K., \& Long, W. (2012). Environmental Kuznets Curve and Pakistan: An empirical analysis. Procedia Economics and Finance 1, 4-13.

Akbostancı, E., Türüt-Aşık, S., \& Tunç, G. İ. (2009). The relationship between income and environment in Turkey: is there an environmental Kuznets curve? Energy policy 37(3), 861867.

Akinlo, A.E. (2008). Energy consumption and economic growth: Evidence from 11Sub-Sahara African countries. Energy Economics 30(5), 2391-2400. 
693 Alam, R., \& Adil, M.H. (2019). Validating the Environmental Kuznets Curve in India: ARDL 694 bound testing framework. OPEC Energy Review 43(3), 277-300.

695 Allard, A., Takman, J., Uddin, G.S., \& Ahmed, A. (2018). The N shaped Environmental 696 Kuznets Curve: an empirical evaluation using a panel quintile regression approach. 697 Environmental science and pollution research 25, 5848-5861.

698 Al-Iriani, M. (2005). Energy-GDP relationship revisited: An example from GCC countries 699 using panel causality. Energy economics 34, 3342-3350.

700 Al-Mulali, U., Saboori, B., \& Ozturk, I. (2015). Investigating the Environmental Kuznets 701 Curve in Vietnam. Energy Policy 76, 123-131.

702 Ang, J.B. (2007). $\mathrm{CO}_{2}$ emissions, energy consumptions, and output in France. Energy Policy $703 \quad 35,4772-4778$.

704 Apergies, N., \& Ozturk, I. (2015). Testing the Environmental Kuznets Curve hypothesis for 705 Asian countries. Ecological Indicators 52, 16-22.

706 Apergis, N., \& Payne, J.E. (2009a). Energy consumption and economic growth in Central 707 America: Evidence from a panel cointegration and error correction model. Energy Economics 708 31(2), 211-216.

709 Apergis, N., \& Payne, J.E. (2009b). Energy consumption and economic growth: Evidence from 710 the Commonwealth of Independent States. Energy Economics 31, 641-647.

711 Appiah, M.O. (2018). Investigating the multivariate Granger causality between energy 712 consumption, economic growth and $\mathrm{CO}_{2}$ emissions in Ghana. Energy Policy 112, 198-208.

713 Asafu-Adjaye, J. (2000). The relationship between energy consumption, energy prices and 714 economic growth: time series evidence from Asian developing countries. Energy Economics 715 22(6), 615-625. 
716 Asghar, Z. (2008). Energy-GDP Relationship: A Causal analysis for the five countries of South

717 Asia. Applied Econometrics and International Development 8(1), 167-180.

718 Bekun, F.V., Emir, F., \& Sarkodie, S.A. (2019). Another look at the relationship between 719 energy consumption, carbon dioxide emissions and economic growth in South Africa. Science 720 of the Total Environment 655, 759-765.

721 Belke, A., Dobnik, F., \& Dreger, C. (2011). Energy consumption and economic growth: New 722 insights into the cointegration relationship. Energy Economics 33, 782-789.

723 Bildirci, M.E. (2013). The analysis of relationship between economic growth and electricity 724 consumption in Africa by ARDL method. Energy Economics Letters 1(1), 1-14.

725 Bilgili, F., Koçak, E., \& Bulut, Ü. (2016). The dynamic impact of renewable energy 726 consumption on CO2 emissions: A revisited Environmental Kuznets Curve approach. 727 Renewable and Sustainable Energy Reviews 54, 838-845. BP Statistical Review of World Energy. (2019).

729 <https://www.bp.com/content/dam/bp/business-sites/en/global/corporate/pdfs/energy-

730 economics/statistical-review/bp-stats-review-2019-full-report.pdf> (access 4 January 2020)

731 Cheng, B.S. (1997). Energy consumption and economic growth in Brazil, Mexico and 732 Venezuela: a time series analysis. Applied Economics Letter 4(11), 671-674.

733 Churchill, S.A., Inekwe, J., Ivanovski, K., \& Smyth, R. (2018). The Environmental Kuznets 734 Curve in the OECD: 1870-2014. Energy Economics 75, 389-399.

736 Kuznets curve. Journal of economic perspectives, 16(1), pp.147-168. 
737 Destek, M.A., \& Sarkodie, S.A. (2019). Investigations of Environmental Kuznets Curve for 738 ecological footprint: the role of energy and financial development. Science of Total 739 Environment 650, 2483-2489.

740 Dinda, S. (2004). Environmental Kuznets curve hypothesis: a survey. Ecological 741 economics 49(4), 431-455.

742 Ding, Y., Zhang, M., Chen, S., Wang, W., \& Nie, R. (2019). The environmental Kuznets curve 743 for PM2. 5 pollution in Beijing-Tianjin-Hebei region of China: A spatial panel data 744 approach. Journal of Cleaner Production, 220, pp.984-994.

745 Dong, K., Sun, R., \& Hochman, G. (2017). Do natural gas and renewable energy consumption 746 lead to less CO2 emission? Empirical evidence from a panel of BRICS countries. Energy 141, $747 \quad 1466-1478$.

748 Economic Survey. (2019-20). Statistical Appendix: Economic Survey 2019-20. <https://www.thehindubusinessline.com/resources/article30701065.ece/binary/Economic\%20 Survey\%20Statistical-Appendix.pdf> (access 16 October 2020)

751 Engle, R.F., \& Granger, C.W.J. (1987). Co-integration and error correction: Representation, 752 estimation and testing. Econometrica 55, 251-276. Fuinhas, J.A., \& Marques, A.C. (2012). Energy consumption and economic growth nexus in 754 Portugal, Italy, Greece, Spain, and Turkey: An ARDL bound test approach (1965-2009). 755 Energy Economics 34, 511-517.

756 Furuoka, F. (2017). Renewable energy consumption and economic development: New findings 757 from the Baltic countries. Renewable and Sustainable Energy Reviews 71, 450-463.

758 Ghosh, S. (2010). Examining carbon emission economic growth nexus for India: A 759 multivariate cointegration approach. Energy Policy 38(6), 3008-3014. 
760

761

762

763

764

765

766

767

768

769

770

771

772

773

774

775

776

777

778

779

780

781

Gorus, M. S., \& Aydin, M. (2019). The relationship between energy consumption, economic growth, and $\mathrm{CO} 2$ emission in MENA countries: causality analysis in the frequency domain. Energy 168, 815-822.

Granger, C.W.J. (1981). Some properties of time series data and their use in econometric model specification. Journal of Econometrics 16, 121-130.

Grossman, G., \& Krueger, A. (1991). Environmental impacts on the North American free trade agreement. NBER working paper No. 3914.

Gunes, S. (2009). Functional income distribution in Turkey: A cointegration and VECM analysis. Journal of Economic and Social Research 9(2), 23-36.

Halicioglu, F. (2009). An econometric study of $\mathrm{CO}_{2}$ emissions, energy consumption, income and foreign trade in Turkey. Energy Policy 37, 1156-1164.

Hamdi, H., Hakimi, A., Sbia, R., \& Jlassi, N.B. (2015), "Financial liberalization and the environmental quality: Evidence from Tunisia”, Energy Studies Review, Vol. 22, pp. 71-94.

He, J., \& Richard, P. (2010). Environmental Kuznets Curve for $\mathrm{CO}_{2}$ in Canada. Ecological Economics 69, 1083-1093.

IEEFA. (2019). International capital awaits a robust policy environment in India's renewable infrastructure sector. <https://ieefa.org/wp-content/uploads/2019/08/International-Capital$\underline{\text { Awaits-Robust-Policy-Environment-in-India-RE-Infrastructure-Sector_August-2019.pdf> }}$ (access 24 March 2021)

International Energy Agency. (2020). India 2020 Energy Policy Review. < https://niti.gov.in/sites/default/files/2020-01/IEA-India\%202020-In-depth-

EnergyPolicy_0.pdf> (access 24 September 2020) 
Işık, C., Ongan, S., \& Özdemir, D. (2019). Testing the EKC hypothesis for ten US states: an application of heterogeneous panel estimation method. Environmental Science \& Pollution Research 26(11), 10846-10853.

Iyke, B.N. (2015). Electrcity consumption and economic growth in Nigeria: A revisit of energy growth debate. Energy Economics 51, 166-176.

Jayanthakumaran, K., Verma, R., \& Liu, Y. (2012). CO2 emissions, energy consumption, trade and income: A comparative analysis of China and India. Energy Policy 42, 450-460.

Jebli, M.B., Youssef, S.B., \& Ozturk, I. (2016). Testing the Environmental Kuznets Curve hypothesis: The role of renewable and non-renewable energy consumption and trade in OECD countries. Ecological Indicators 60, 824-831.

Jebli, M.B., \& Youssef, S.B. (2017). The role of renewable energy and agriculture in reducing $\mathrm{CO}_{2}$ emissions: Evidence for North Africa Countries. Ecological Indicators 74, 195-301.

Johansen, S. (1996). Likelihood based inference in cointegrated in Vector Autoregressive Model. Oxford University Press, Oxford.

Johansen, S., \& Juselius, K. (1990). Maximum likelihood estimation and inference on cointegration- with applications to the demand for money. Oxford Bulletin of Economic and Statistics 52(2), 169-210.

Kanjilal, K., \& Ghsoh, S. (2013). Environmental Kuznets Curve for India: Evidence from tests of conitegration with unknown structural breaks. Energy Policy 56, 509-515.

Kuznets, S. (1955). Economic growth and income inequality. The American economic review, 45(1), pp.1-28. 
804 Curve for carbon emissions in Malaysia: Do foreign direct investment and trade matter? Energy 805 Policy 68, 490-497.

806 Lorente, D.B., \& Alvarez-Herranz, A. (2016). An approach to the effect of energy innovation on environmental Kuznets curve: An introduction to inflection point. Bulletin of Energy Economics 4(3), 224-233.

Mahmood, N., Danish, Wang, Z., \& Zhang, B. (2020). The role of nuclear energy in the 810 correction of environmental pollution: Evidence from Pakistan. Nuclear Engineering and 811 Technology, 52(6), 1327-1333.

Majid, M.A. (2020). Renewable energy for sustainable development in India: current status, 813 future prospects, challenges, employment, and investment opportunities. Energy, 814 Sustainability and Society, 10(1), pp.1-36.

815 Mazzucato, M., \& Semieniuk, G. (2018). Financing renewable energy: Who is financing what 816 and why it matters. Technological Forecasting and Social Change 127, 8-22.

817 Menéndez, A.J.L., Pérez, R., \& Moreno, B. (2014). Environmental costs and renewable energy: 818 Re-visiting the Environmental Kuznets Curve. Journal of Environmental Management 145, $819 \quad 368-373$.

820 Ministry of Environment, Forest and Climate Change. (2015), "India's Intended Nationally 821 Determined Contributions is balanced and comprehensive: Environment Minister", available at: https://pib.gov.in/newsite/PrintRelease.aspx?relid=128403 (accessed 20 December 2019). 

2019).

827 Narayan, P.K. (2005). The saving and investment nexus for China: evidence from cointegration 828 tests. Applied Economics 37(17), 1979-1990.

829 Nazlioglu, S., Kayhan, S., \& Adiguzel, U. (2014). Electricity consumption and economic 830 growth in Turkey: Cointegration, Linear and Nonlinear Granger Causality. Energy Source part 831 B: Economics, Planning and policy 9(4), 315-324.

832 Nasir, M., \& Rehman, F.U. (2011). Environmental Kuznets Curve for carbon emissions in 833 Pakistan: an empirical investigation. Energy Policy 39, 1857-1864.

834 NITI Aayog. (2017). Draft National Energy Policy. Government of India. 835 <https://niti.gov.in/writereaddata/files/new_initiatives/NEP-ID_27.06.2017.pdf> (accessed 28 836 December 2019).

837 NSO, Ministry of Statistics and Programme Implementation, GoI. Energy Statistics 2020.

838 〈http://www.mospi.gov.in/sites/default/files/publication_reports/ES_2020_240420m.pdf>

839 (access 20 October 2020)

840 Özokcu, S., \& Özdemir, Ö. (2017). Economic growth, energy, and Environmental Kuznets 841 curve. Renewable and Sustainable Energy Reviews 72, 639-647.

842 Pal, D., \& Mitra, S.K. (2017). The environmental Kuznets curve for carbon dioxide in India 843 and China: Growth and pollution at crossroad. Journal of Policy Modeling 39, 371-385.

844 Pata, U.K. (2018). Renewable energy consumption, urbanization, financial development, 845 income and $\mathrm{CO}_{2}$ emission in Turkey: Testing EKC hypothesis with structural breaks. Journal 846 of Cleaner Production 187, 770-779. 
847 Pesaran, M.H., \& Shin, Y. (1998). An autoregressive distributive-lag modelling approach to 848 cointegration analysis. Econometric Society Monographs 31, 371-413.

849 Pesaran, M.H., Shin, Y., \& Smith, R.J. (2001). Bound testing approaches to the analysis of 850 level relationships. Journal of Applied Econometrics 16(3), 289-326.

851 Phillips, P.C.B., \& Hansen, B.E. (1990). Statistical inference in instrumental variables regression with I(1) processes. Review of Economic Studies 57, 99-125.

Press Information Bureau, Ministry of Commerce \& Industry, Government of India, (2020). <https://pib.gov.in/newsite/PrintRelease.aspx?relid=200378> (access 22 January, 2021).

Rahman, Z.U., \& Ahmad, M. (2019). Modeling the relationship between gross capital formation and $\mathrm{CO} 2$ (a) symmetrically in the case of Pakistan: an empirical analysis through NARDL approach. Environmental Science and Pollution Research 26, 8111-8124.

Rana, R., \& Sharma, M. (2018). Dynamic causality testing for EKC hypothesis, pollution heaven hypothesis and international trade in India. The journal of International Trade \& Economic Development 28(3), 348-364.

Rej, S., \& Nag, B. (2018). Does socio economic development impact energy consumption? A causality test for India. Journal of Energy and Development 44(1), 143-159.

Rej, S., \& Nag, B. (2021). Energy crossroads and prioritization of energy choices: Case of India. OPEC Energy Review.

Saboori, B., Sulaiman, J., \& Mohd, S. (2012). Economic growth and CO2 emissions in Malaysia: A cointegration analysis of the Environmental Kuznets Curve. Energy Policy 51, 184-191.

Sarkodie, S. A., \& Strezov, V. (2019). A review on environmental Kuznets curve hypothesis using bibliometric and meta-analysis. Science of the total environment 649, 128-145. 
Sebri, M., \& Ben- Salha, O. (2014). On the causal dynamics between economic growth, renewable energy consumption, $\mathrm{CO} 2$ emissions and trade openness: Fresh evidence from BRICS countries. Renewable and Sustainable Energy Reviews 39, 14-23.

Shafik, N., \& Bandyopadhyay, S. (1992). Economic Growth and Environmental Quality: Time series and cross country evidence. World Bank Publications.

Sinha, A., \& Shahbaz, M. (2018). Estimation of Environmental Kuznets Curve for $\mathrm{CO}_{2}$ emission: Role of renewable energy generation in India. Renewable Energy 119, 703-711.

Soytas, U., \& Sari, R. (2003). Energy consumption and GDP: causality relationship in G-7 countries and emerging markets. Energy Economics 25(1), 33-37.

Soytas, U., Sari, R., \& Ewing, B.T. (2007). Energy consumption, income and carbon emissions in the United States. Ecological Economics 62, 482-489.

Srikanth, R. (2018). India's sustainable development goals-Glide path for India's power sector. Energy Policy 123, 325-336.

Thangavelu, S.M., \& Rajaguru, G. (2004), "Is there an export or import-led productivity growth in rapidly developing Asian countries? A multivariate VAR analysis", Applied Economics, Vol. 36, pp. 1083-1093.

Tiwari, A.K., Shahbaz, M., \& Hye, Q.M.A. (2013). The Environmental Kuznets Curve and the roal of coal consumption in India: cointegration and causality analysis in an open economy. Renewable and Sustainable Energy Reviews 18, 519-527.

Tugcu, C.T., Ozturk, I., \& Aslan, A. (2012). Renewable and non-renewable energy consumption and economic growth relationship revisited: Evidence from G-7 countries. Energy Economics 34(6), 1942-1950. 
892 UNFCCC. (2015). India's intended nationally determined contribution: working towards 893 climatejustice.<http://www4.unfccc.int/ndcregistry/PublishedDocuments/India\%20First/INDI 894 A\%20INDC\%20TO\%20UNFCCC.pdf> (access 4 October 2020)

895 Wang, Y., Han, R., \& Kubota, J. (2016). Is there an Environmental Kuznets Curve for $\mathrm{SO}_{2}$ 896 emissions? A semi parametric panel data analysis for China. Renewable and Sustainable 897 Energy Reviews 54, 1182-1188.

898 World Economic Forum. (2019). <https://www.weforum.org/agenda/2019/09/global899 renewable-energy-investment-slowing-down-worry/ > (access 24 March 2021)

900 World Bank data. (2019). 〈https://data.worldbank.org/> (access 4 January 2020) 